\title{
Hysteresis effect in suspended sediment concentration in Kutinska River basin
}

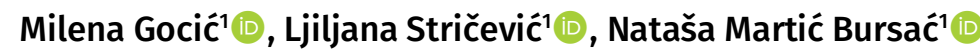 \\ 'Faculty of Sciences and Mathematics, Department of Geography, Višegradska 33, Niš, Serbia
}

\section{Keywords:}

Suspended sediment Discharge

Hysteresis loops.

\begin{abstract}
Changes in the suspended sediment load of a river have important impacts on river morphology, sedimentation process, nutrient flux, aquatic ecology. The hysteresis effects show the relationship between the concentration of suspended sediment and the discharge. This relationship can be observed on the basis of data on mean annual values or an individual storm event. This one year study utilizes a hysteresis from suspended sediment and discharge data to assess fluctuations in sediment source location, delivery mechanisms in Kutinska river basin. The hysteresis loops on the Kutinska river are the figure eight shape, which indicates complex conditions in river basin. It contains elements of clockwise hysteresis as well as elements of counter-clockwise. The figure eight hysteresis indicates complex conditions in the dynamics and transport of suspended sediment and shows the order of dominant conditions that occur after dry preconditions. Hysteresis analysis successfully indicated contrasting seasonality, connectivity and source availability and is a useful tool to identify watershed specific sediment management practices.
\end{abstract}

\section{Introduction}

Sediments from catchments are often absorbed by nutrients, heavy metals and pollutants that can affect river environments. To mitigate erosion, sediment transport, and the transport of pollutants, it is cru-cial to know the origin of the sediment found in the drainage system, and to understand the dynamics of the sediment during the extreme runoff. Continuous attention to climate change in the world, Europe, Ser-bia contributes to the growing interest in detailed studies of contemporary sediment dynamics in basins. The inadequate level of research is attributed to the lack of measurement profiles on watercourses and the lack of long-term data on discharges and concentration of suspended sediment on rivers.

Factors that control the transport of suspended sediment are numerous, precipitation, runoff, lithological composition of basin (Chakrapani, 2005), basin size (Meybeck et al., 2003), local topography, soil proper-ties, climate, vegetation cover, catchment morphology, drainage network characteristics, land use (Restrepo et al., 2006). Lavee et al. (1996) reported that soil temperature and moisture affect the stability of soil and thus the intensity of soil erosion. Changes in the availability of sediment results in hysteresis effects (Bača, 2008).

Climatic and tectonic factors are of the greatest importance because they indicate the potential of sediments to move, erode, the amount of water needed to transport sediments. Almost all suspended sediment loads are transported during storm events that mainly occur in late spring. The reduction of extreme precipitation in some months leads to a large interseasonal variability in the concentration of suspended sediment.

Based on the previous analyses (Nikolić, 2019; Manojlović, 2018), it has been clearly recognized that un-der the influence of extreme hydrological conditions for one month, november 2016, $60 \%$ of the annual suspended sediment yield have been evacuated from the Kutinska River basin. 
The Kutinska river basin is characterized by a large variability of suspended sediment concentrations. In addition to this variability, the river is also characterized by variability of discharge. By comparing the data on the concentration of suspended sediment (SSC) and discharge (Q), it can be determined how the con-centrations of suspended sediment are distributed in relation to the discharges on an intra-annual level. One of the indicators of the connection between the concentration of suspended sediment and discharge is the determination of the existence of a hysteresis effect. This relationship can be observed on the basis of data on mean multi-year values or an individual event during the passage of the flood wave within different seasons (Grenfell and Ellery, 2009; Soler et al., 2008; Alexandrov et al., 2007). In any case taken into con-sideration, the identification of different types of hysteresis loops indicates the type and location of sedi-ment sources, as well as the dominant conditions of the runoff and denudation process, which results in different transport of denudation material to rivers. Williams (1989) singles out five types of loops, but a complex loop, in the shape of eight, appears on the investigated basin.

Most studies (Walling and Webb, 1981; Van Sickle and Beschta, 1983; Bača, 2001; Picouet et al., 2001) explain the hysteresis loops in a clockwise direction where the concentration of suspended sediment reach-es a maximum value before the discharge reaches a maximum during a storm event. Hysteresis counter-clockwise occurs due to riverbank collapse (Sarma, 1986; Ashbridge, 1995; Russel et al., 2001) or sediment originate from distant sources (Klein, 1984).

The hysteresis loop on the Kutinska river are complex, the figure eight. It contains loop elements clockwise as well as loop elements counter-clockwise. The eight-shape loop can be understood as a sequence of dom-inant conditions. It occurs when there is little water in the riverbed. Here, the process of runoff is repre-sented by the infiltration of excess water, which causes the rapid spread of sediments in areas near the stream and throughout the entire basin.

The assessment of suspended sediment transport is of great importance for planning at the local and regional level, including the design of hydropower facilities, but also the management of water and land re-sources for the purpose of ecological protection of space.

The aim of the paper is to explain the hysteresis effect on the Kutinska River. The data necessary to explain this effect are the daily values of discharge and concentration of suspended sediment during 2016 at the hydrological station of Radikina Bare. An eight-shaped loop has been determined, which indicates the complex conditions that operate on the territory of the basin.

\section{Study area}

The Kutinska River basin covers approximately $231 \mathrm{~km} 2$ of the territory of the Republic of Serbia with a total length of $43.03 \mathrm{~km}$. Basin area lies between $21^{\circ} 57^{\prime} 39^{\prime \prime}$ and $22^{\circ} 13^{\prime} 29^{\prime \prime} \mathrm{E}$ longitude and $43^{\circ} 04^{\prime} 49^{\prime \prime}$ and $43^{\circ} 18^{\prime} 14^{\prime \prime} \mathrm{N}$ latitude. The lowest point in the basin is the confluence of the Kutinska River with Nišava near city of Niš at $203 \mathrm{~m}$ above sea level, while the highest point in the basin is the highest peak of Suva planina mountain, Trem (1810 m) (Figure 1). The basin geology consist of albite-chlorite-sericite schists from Proterozoic that form the basis of the mountains Seličevica and Babička Gora to the south and west of the basin, cretaceous and dolomite from Mesozoic are present on Suva Planina mountain, while Pliocene sediments, gravel and sand, are pre-sent in the peripheral parts of the Niš basin and along the river. The basin is located in the area under the influence of a moderate continental climate. The average annual air temperature in the basin is $9.12^{\circ} \mathrm{C}$. The average annual rainfall in the basin is $767 \mathrm{~mm}$ (for period 1961-2016). The lower parts of the basin represent the area with the least amount of precipita-tion in Serbia, below $600 \mathrm{~mm}$, while the higher parts of the basin (over $1000 \mathrm{~m}$ ) receive approximately $950 \mathrm{~mm}$ of precipitation per year.

\section{Materials and methods}

Data on daily discharge (Q) values for the period 1961-2016 at the hydrological station Radikine Bare on the Kutinska river were taken from the Republic Hydrometeorological Service of Serbia (www.hidmet.gov.rs). On the Kutinska River, there has never been a measurement of the suspended sediment. Data on daily values of suspended sediment concentrations (SSC) for 2016 were obtained by own sampling on the same hydrological profile as the discharge values.

Sediment monitoring methodology is standard and consists of daily sampling of water and sediment, with laboratory determination of the suspended sediment concentration. Samples were collected manually using a $1000 \mathrm{ml}$ plastic bottle. The water samples were then filtered through quantitative filter paper (Whatman). Filters were further dried at $105{ }^{\circ} \mathrm{C}$ for 2 hours and weighted on the analytical balance. The filter papers were first measured empty, and when the sample was filtered, they were dried in a dryer and remeasured on an analytical balance, and the difference in weight of 


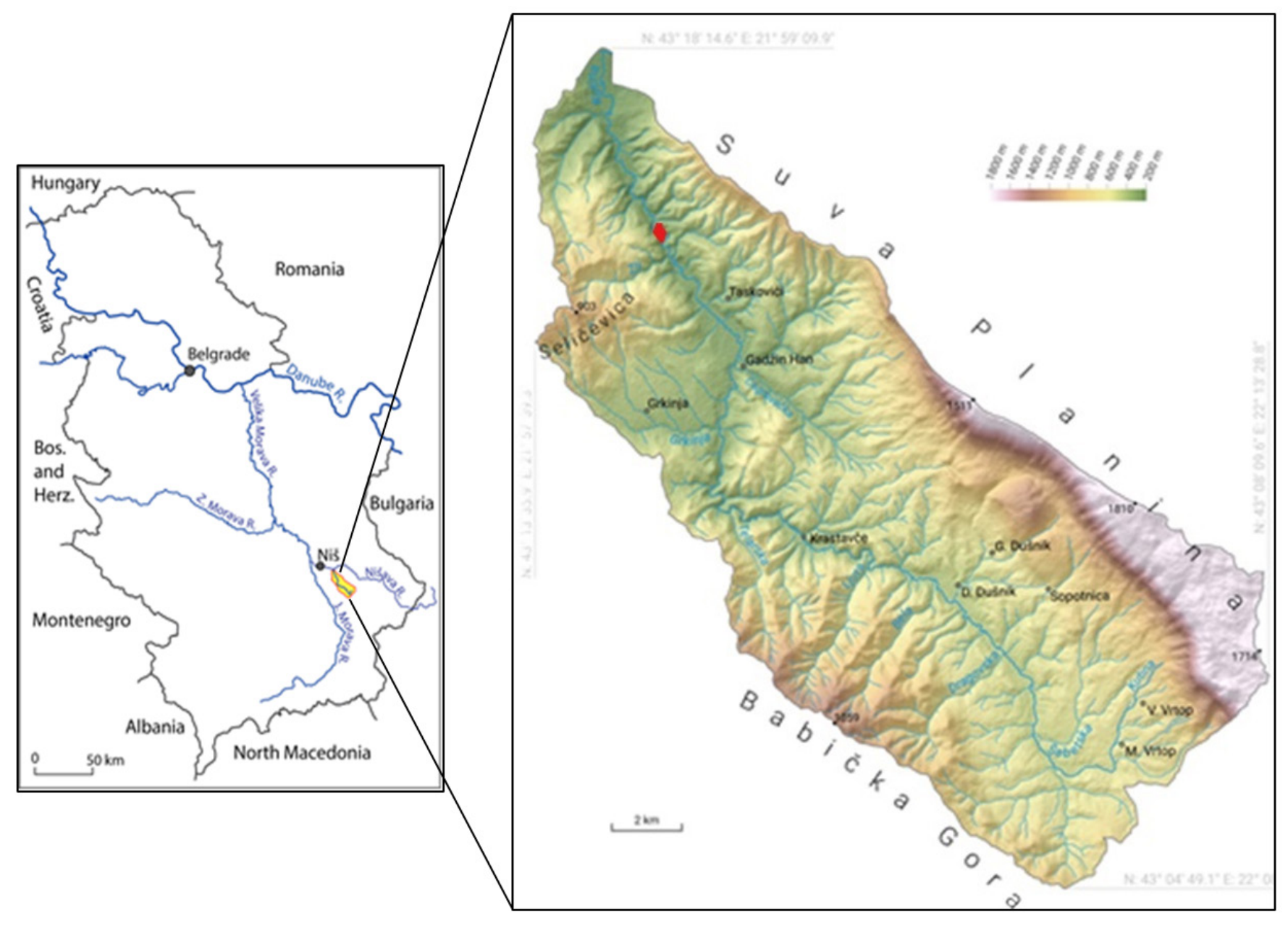

Figure 1. Geographical position of the Kutinska River basin in the Republic of Serbia (left) and relief map of the basin (right) (red symbol represent position of hydrological station).

filter paper full and empty represents concentration of suspended sediment. The monitoring of the suspended sediment was performed daily during 2016, and more often during the increase of the discharge. All analytical procedures were done in the Laboratory of Physical Geography on the Faculty of Geography, University of Belgrade.

\section{Results and discussion}

The movement of the suspended sediment during the increase of the discharge is in the function of variation in sediment supply and sediment depletion. Such changes in the availability of suspended sediment result in the existence of a hysteresis effect.

The shape of the hysteresis loop depends on a number of factors, such as precipitation, location or source of sediment production, basin size (Zabaleta et al., 2007; Soler et al., 2008), soil moisture (Klein, 1984). Soil plays a major role in runoff. Primarily due to the infiltration capacity of the soil and its ability to retain rainwater. For that reason, in some basins, the height of runoff is determined by the characteristics of the soil more than amount of precipitation (Mustafić, 2013).

The values of suspended sediment concentrations are low during most of the year, so that the determination of the existence of a hysteresis is most often considered over the average annual values. Out of five types of loops (Williams, 1989) in the Kutinska river basin for 2016, was found the figure eight loop. In complex loops (eight-shaped), quantitative analysis shows that soil moisture explains $80 \%$ of the variance of all observed flood waves. Hysteresis are explained by different levels of humidity and precipitation and are therefore indicators of different processes of runoff and sediment transport (Seeger et al., 2004).

The hysteresis loop on the Kutinska river is the figure eight shape, which is in line with the research of Mustafić (2013). In the phase of the loop in the clockwise direction, the supersaturation of macro and micro pores in the soil occurs, and its capacity to retain water is small, so that the conditions of swelling intensify. In this case, soil conditions 
stand out as the dominant factor. When the loop is in the opposite direction (counter-clockwise), a situation arises which is dominated by high-intensity precipitation, which means that the source of sediments can be active in a wider area of the basin. In the case of a hysteresis loop counter-clockwise, the reason for the appearance of a high concentration of sediment after the peak discharge is the long-term transfer of sediments to watercourses, because sediments are transported from areas that are very far from it. This indirectly indicates a low density of the river network and thus a lower rate of runoff. Sediments originate from areas that are not permanently connected to the channel network. These areas are connected in a single network only when the runoff is intense in a wider area, which happens when there is extremely high rainfall and high soil moisture saturation (Manojlović, 2018). Soil oversaturation with moisture causes intensive runoff regardless of the topographic characteristics of the terrain (Seeger et al., 2004).

The hysteresis for 2016 is unusual, because it has pronounced peaks due to extreme values of discharge and concentration of suspended sediment in March and November. The year 2016 is characterized by a large amount of precipitation are fairly unevenly distributed (mostly in January, May, July, October and November, while the other months are below the annual average of monthly precipitation). The loop starts clockwise, where the discharges decrease from January to February, and the concentrations of suspended sediment increase (Figure 2). It is characterized by a sudden increase in suspended sediment concentration (MarchApril), rapid removal of sediments from the area near the river flow as well as from the riverbed itself, which are characterized as short-lived events (Mustafić, 2013). The year 2016 stands out as extremely watery and wet according to the amount of precipitation, but the influence of the season, primarily precipitation, is not a decisive factor in terms of suspended sediment concentration. As the amount of precipitation decreases (the slope of the trend line is extremely steep), it means that the sources of sedimentary sediment are limited and that they are quickly depleted. That is, that runoff conditions and sediment mobility are limited to areas near the river flow. In March, the discharges reaches maximum values, which is in line with the perennial average of maximum discharges. In the period from January to March, the concentrations gradually increase. After that (from March to September), extremely low discharges are recorded, much lower than the perennial averages, which is accompanied by a decrease in suspended sediment concentrations. Such low discharges are not in line with the amount of precipitation that is high during the year. However, the precipitation is not evenly distributed, so that the months that receive small amount of precipitation do not coincide with the months that are characterized by low discharges. January, October and November are characterized as months with a large amount of precipitation, and with a lot of days with precipitation over $10 \mathrm{~mm}$ than the average values (for the period 1961-2016). From October, the concentration of suspended sediment begins to increase until November, when the maximum values are reached (Figure 2), but the discharge is slightly above average, which can be explained by higher (above average values) precipitation in October

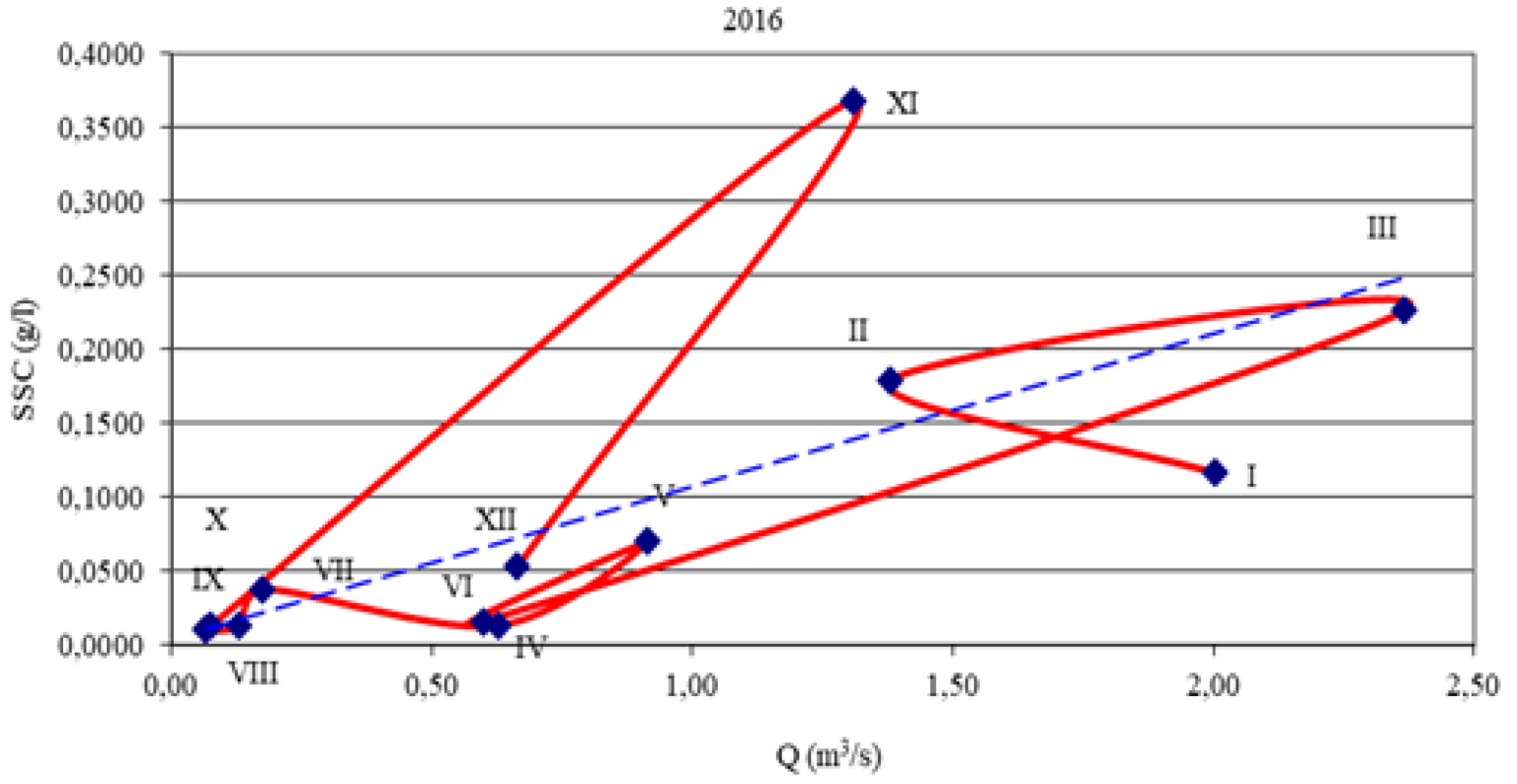

Figure 2. Mean annual hysteresis loop in 2016, profile of Radikine Bare, Kutinska River. 
and November. This year stands out as slightly dry according to the classification by watery conditions but wet according to the amount of precipitation, so the influence of the season, as already mentioned, is not a decisive factor in high concentrations of suspended sediment.

Looking at the Figure 2, we can conclude that the data are more scattered during the spring months compared to the trend line. After that, the concentration of suspended sediment decreases, so the data are less scattered, especially during the summer, autumn and the beginning of winter. During the winter period, especially during the gradual melting of the snow cover, the erosion process consists in removing loose fine-grained soil particles from the slopes of the terrain, so the transport of suspended sediment takes place in conditions of low discharges. It is characteristic for the Kutinska River basin that the concentrations of suspended sediment reach a maximum when are the maximum discharge values, which was also determined for the Nišava River basin (Manojlović, 2018) and basins in Siberia (Tananaev, 2015).

Studies indicate a significant role of forest cover, a strong relationship between the value of sediment concentration and the area under the forest complex. Because of the forest cover, the production of material is low, which means that the amount of sediment available for transport to the river is also low (Zabaleta et al., 2007; Erskine et al., 2003). Forests reduce the intensity of erosion and have more positive effects, prevent sudden runoff of water from the surface of the terrain after intense rainfall, so that heavy, downpour rains do not affect the sudden increase in discharge but reduce the peak of floods (Živković et al., 2015). The forest cover reduces slopes and increases water infiltration and thus reduces surface runoff. It also affects the quality of the soil cover, which increases its resistance to erosion (Kostadinov, 2010).

\section{Conclusion}

Using available information on the annual suspended sediment concentrations for 2016, the authors tried to explain the effect of hysteresis on the investigated river. Changes in discharges depend primarily on the climate. Most of the suspended sediments in the rivers are transported during sudden increases in discharge, so that the relationship between $\mathrm{Q}$ and SSC is complex. By linking the discharge and concentration of suspended sediment, we tried to explain the hysteresis effect by the reasons for the change of suspended sediment in the river, the mechanism of their movement and their transport to river. Loop for 2016 on Kutinska River has two peaks, in March and November. During those two months, the maximum values of discharge and concentration of suspended sediment were recorded. The loop starts clockwise, with an increase in discharges during the winter months and early spring, with the maximum discharge values in March. From March there is a sharp decrease in discharges and then the loop of the opposite direction begins (counter-clockwise). As the values of discharge decreases, the concentration of suspended sediment also decreases. From October, an increase in the value of discharge and concentration of suspended sediment begins again, where the concentrations of suspended sediment reach maximum values in November, which is not characteristic for rivers in Serbia. Analysis have showed that the largest concentrations of suspended sediment appear when are the maximum values of discharges. During 2016, the authors determined an eight-shaped loop in the Kutinska River and determined that the most important factor is soil moisture, which explains the production of sediments when high discharges occur. Due to the saturation of the soil with moisture, in addition to the soil conditions, intense precipitation also stands out, as a result of which the soil is oversaturated with water. In these cases, loops of different directions appear, which results in the appearance of a complex loop during the research period. Understanding the hysteresis effect, its relationship to sediment dynamics aims to improve the efficiency of the assessment of suspended sediment estimation and better predictions for ungauged river basins.

\section{ORCID iDs}

Milena Gocić (i) https://orcid.org/0000-0003-1490-0838 Ljiljana Stričević (1) https://orcid.org/0000-0002-0574-2009 Nataša Martić Bursać (i) https://orcid.org/0000-0002-9142-8509

\section{References}

Alexsandrov, Y., Laronne, J.B., Reid, I., 2007. Intra event and inter seasonal behaviour of suspended sed-iment in flash floods of the semi-arid northern Negev, Israel. Geomorphology 85, 85-97.

Ashbridge, D., 1995. Processes of river bank erosion and their contribution to the suspended sediment load of the River Culm, Devon. In: Sediment and Water Quality in River Catchments, 229-245. Wiley, Chichester, UK.

Chakrapani, G. J., 2005. Factors controlling variations in river sediment loads. Current Science, 88, 569-575.

Bača, P., 2001. Analyses and modelling of surface runoff and erosion process in a small basin. Acta Hy-drologica Slovaca, 2(1), 93-97. 
Bača, P., 2008. Hysteresis effect in suspended sediment concentration in the Rybárik basin, Slovakia. Hy-drol. Sci. J., 53 (1), 224-235.

Erskine, W., Mahmoudzadeh, A., Browning, C.M., Mayers, C., 2003. Sediment yields and soil loss rates from different land uses on Triassic Shales in western Sydney, NSW. Australian Journal of soil re-search, 41 (1), 127-140.

Grenfell, S.E., Ellery, W.N., 2009. Hydrology, sediment transport dynamics and geomorphology of a vari-able flow river. The Mfolozi River, South Africa. African Research, 35 (3), 27-282.

Lavee, H., Sarah, P., Imeson, A. C., 1996. Aggregate stability dynamics as affected by soil temperature and moisture regimes. Geografiska Annaler. Series A Phys. Geogr., 78(1), 73-82.

Klein, M., 1984. Anti clockwise hysteresis in suspended sediment concentration during individual storms. Catena, 11, 251-257.

Kostadinov, S., 2010. Forests in Serbia as the factor of Soil and Water Protection against Degradation in the Conditions of Global Climate Change. In: Alexandrov et al. (eds.), Global Environmental Change: Challenges to Science and Society in Southeastern Europe. Springer Science, Business Media BV, pp.177-190.

Manojlović, S., 2018. Influence of geographical factors on changes in water erosion intensity in the Nisava River basin. Faculty of Geography, Belgrade, 1-192.

Meybeck, M., Laroche, L., Durr, H.H., Syvitski, J.P.M., 2003. Global variability of daily total suspended solids and their fluxes in rivers. Global and Planetary Change, 39, 65-93.

Mustafić, S., 2013. Geographical factors as determinants of erosion intensity on the example of the Nisava River basin. Doctoral dissertation, Faculty of Geography, Belgrade.

Nikolić, M., 2019. Influence of natural and anthropogenic factors on erosion intensity in Jablanica and Kutinska river basins. Doctoral dissertation, Faculty of Geography, Belgrade.

Picouet, C., Hingray, B., Olivry, J. C., 2001. Empirical and conceptual modelling of the suspended sedi-ment dynamics in a large tropical African river: the Upper Niger river basin. J. Hydrol. 250, 19-39.

Restrepo, J.D., Kjerfve, B., Hermelin, M., Restrepo, J.C., 2006. Factors controlling sediment yield in a ma-jor South American drainage basin: the Magdalena River, Colombia. Journal of Hydrology, 316 (1-4), 213-232.
Russell, M. A., Walling, D. E., Hodgkinson, R. A., 2001. Suspended sediment sources in two small lowland agricultural catchments in the UK. J. Hydrol., 252, 1-24.

Sarma, J. N., 1986. Sediment transport in the Burhi Dihing River, India. In: Drainage Basin Sediment De-livery (ed. By R. F. Hadley), 199-215. IAHS Publ. 159. IAHS Press, Wallingford, UK.

Seeger, M., Errea, M.P., Begueria, S., Arnaez, J., Marti, C., Garcia-Ruiz, J.M., 2004. Catchment soil mois-ture and rainfall characteristics as determinant factors for discharge/suspended sediment hysteretic loops in a small headwater catchment in the Spanish Pyrenees. Journal of Hydrology, 288, 299-311.

Soler, M., Latron, J., Gallart, F., 2008. Relationships between suspended sediment concentrations and dis-charge in two small research basins in a mountainous Mediterranean area (Vellcebre, Eastern Pyre-nees). Geomorphology 98, 143-152.

Tananaev, N., 2015. Hysteresis effects of suspended sediment transport in relation to geomorphic condi-tions and dominant sediment sources in medium and large rivers of the Russian Arctic. Hydrology Re-search, 46 (2), 232-243.

Van Sickle, J., Beschta, R. L., 1983. Supply-based models of suspended sediment transport in streams. Water Resour. Res. 19, 768-778.

Walling, D. E., Webb, B. W., 1981. The reliability of suspended load data. In: Erosion and Sediment Transport Measurement (Proc. Florence Symp.), 177-194. IAHS Publ. 133. IAHS Press, Wallingford, UK.

Williams, G.P., 1989. Sediment concentration versus water discharge during single hydrologic events in rivers. Journal of Hydrology, 111, 89-106.

www.hidmet.gov.rs (last access 19.03.2019.)

Zabaleta, A., Martinez, M., Uriarte, J.A., Antiguedad, I., 2007. Factors controlling suspended sediment yield during runoff events in small headwater catchment on the Basque Country. Catena, 71 (1), 179-190.

Živković, N., Dragićević, S., Ristić, R., Novković, I., Djurdjić, S., Luković, J., Živković, Lj., Jovanović, S., 2015. Effects of vegetation on runoff in small river basins in Serbia. Fresenius Environmental Bulle-tin, 24 (6), 2082-2089. 